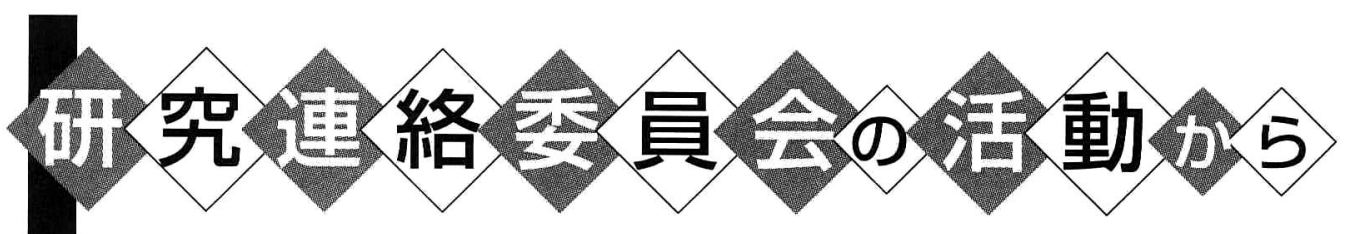

地質科学関連学協会連合・地質学研究連絡委員会共催 〈地質科学シンポジウム $>$

\section{地質工学および関連分野における 技術者養成と大学教育}

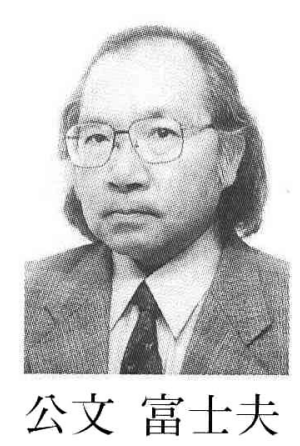

\section{経過}

このシンポジウムは、日本地質学会・日本古 生物学会・東京地学協会・日本岩石鉱物学会. 応用地質学会などで構成する地質科学学協会連 合と日本学術会議第4部に属する地質学研究連絡 委員会との共催で開催いたしました。前者は地 質科学に関連する学協会が連携をとりながら、 地質科学の普及と発展を四ろうと、2000年3月 27 日に発足したものです。地質学研究連絡委員会 でも第17期から、地質科学の発展にとって社会 的役割の桩大が重要な課題として認識され、シ ンポジゥムの開催などが検討されていました。

一方、高い資質をもつ技術者の有成とその国際 認証をめざす日本技術者教育認定機構 (JABEE) が1999年11月に発足したことに対応して、地質 亡学分野の参画をめざして、関連諸学会が協力 しながら各種の努力を行っていました。また、 技術士制度も、その国際的同等性の確保を念頭 において2000年4月1日に改正がなされ、継続的 な白主的研修が義務づけられることになりまし
た。応用理学という領域には2000名を超える地 質科学関連の技術士がおり、諸学会が技術者の 継続教育に共同して取り組むことが求められて いました。

このような状況の中で、地質科学関連分野が 一堂に集まって、科学技術動向と後継者養成の 現状を認識し、様々な立場から改革の提言をだ しあう機運が盛り上がってきて打り、このシン ポジウムを開催するに至りました。

\section{目的}

シンポジウムの課題は、「21世紀に入り、科学 技術を有効に生かした社会の持続的発展に対す る地質工学分野の科学と技術の役割は一層大き なものとなるものと考えられる。一方、それを 担う人材を育成すべき大学では、学生の学力低 下や教育システムの桎梏、教育予算の削減など によって危機的な状沉が進行している。このよ うな中で、JABEEが発足し、大学卒業した技術 者についての高い資質の確保、それを保証する 教育カリキュラムの整備、技術者資格の国際的 
認証による活躍分野の国際化などを図っている。 このような技術者育成をめぐる急激な情勢変化 を踏まえながら、地質科学分野において求めら れる技術者像とそれを育成するための高等(大学) 教育の改革などを幅広い視野から議論して、改 善の方向を探る」こととし、以下の方々に講演し てきただきました。

1）球科学のニューフロンティアと後継者養成 （日本学術会議会員 斎藤常正）

2）日本技術者教育認定機構 (JABEE) の最近の 動向 (早稲田大・理工 大和田秀二)、

3）地質工学分野の分野別基準案 (京大 - 防災研 究所千木良雅弘)、

4） 21 世紀に地質工学が果たすべき社会的役割 (応用地質 (株) 会長 大矢 暁)、

5）コンサルタント企業が求める地質技術者像 （(社）全国地質調查業協会連合会専務理事 矢島壮一)、

6）島根大学に扔ける地質工学教育とJABEE試行 への取り組み (島根大・総合理工・地球環境 資源学科 横田修一郎)、

7）資源分野に打ける2000年度JABEE試行審査 について(東京大·工学系研究科 山冨二郎)、

8）技術士継続教育の課題と地質工学 (応用理学) 分野の取り組み (大阪市立大・理。中川康一)

\section{成果}

地球科学をめぐる最新の状況、JABEEの役割、 地質工学打よび関連分野におけるJABEE認定の
分野と基準の設定状沉、地質科学および技術の 歴史的展開と 21 世紀に打ける役割、地質工学の 現場とそこに求められる技術者像、技術者を養 成する大学の取り組み、大学に扔ける技術者養 成の視点 (資源 · 素材分野の例)、技術者継続教 育の課題、といったそれぞれの課題について最 適の方に講演していただくことができ、現状認 識と問題意識に扎いて幅広い共通認識をもつこ とができました。

特に、これまでは分散しがちであった地球科 学の諸分野に打いて、諸学協会や産業界が一緒 になった総合的な場を設け、産業界と大学の関 係者が意見を述べあい、理解を深めることがで きたことに大きな意味があったといえます。地 質工学分野全体が日本の基幹産業のひとつとし て成長していってほしいという期待がそこには こめられていました。

今回だけでは議論は尽きなかったし、状況の 変化の中で議論すべきことがらも今後変化して いくだろうから、このような産学合同の討論の 場を今後もぜひ継続したいと言う意見も多く聞 かれました。

講演の中で、(1)社会発展の歴史的視点にたっ たとき、今は平成の維新といっても良い社会変 革期である、(2)地質工学扎よびその関連分野は 20世紀には産業化社会の足もとを築く役割を担 つてきたが、21世紀には社会の持続的発展を可 能とする総合的な環境デザインづくりで活躍す ることが求められていること、(3)それを可能と 
するようなインテグレートされた科学として地 質工学およびその関連分野を発展させる必要が あること、などが指摘されたことは重要でした。

\section{今後の計画}

JABEE関係では、先行していた資源・素材分 野との合同が実現し、「地球・資源およびその関 連分野」が確立しました。平成13年度の試行審査 が3コースで予定されていますが、その審査結果 などを受けて、この課題への共通認識を一層深 めるためのシンポジウムを企画しています。ま
た、自然災害等の危険の大きな日本列島に賢く 住み続けるためには地学の知識が不可欠との認 識に立って、地質科学の普及と社会への還元を 目指して、各種のシンポジゥム・講演会・研修 会などに取り組む準備を進めています。課題は たくさんありますが、できるところから着実に 歩みを進めたいと考えています。

公文 富士夫（くもんふふじお 1950年生） 日本学術会議地質学研究連絡委員会幹事、信州大学理学部 教授

専門：地質学、堆積学

\section{月刊「学術の動向」広告掲載のご案内}

\section{広告料等}

料金

\begin{tabular}{lllll}
\hline 区分 & スペース & 刷り色 & 広告料 & 備考 \\
\hline 表3 & $1 / 1$ & 1色 & $150,000 \mathrm{円}$ & スペースは1/2提供可 \\
\hline 表4 & $1 / 1$ & 4色 & $300,000 \mathrm{円}$ & \\
\hline ページ中 & $1 / 4$ & 1色 & $10,000 \mathrm{円}$ & 発行月により1/2スペース利用可 \\
\hline
\end{tabular}

(注)・6力月以上継続してご契約される場合は、広告料を割引きさせていただきます。 ・ページ中の広告スペースは、学術研究団体、大学、書店向けです。

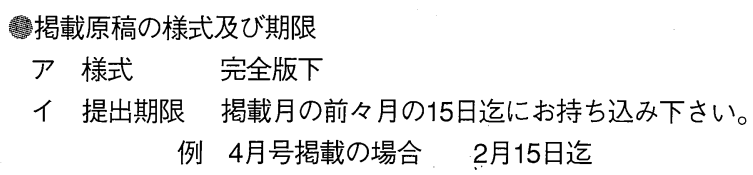

\section{お間い合わせ・連絡先}

（財)日本学術協力財団 =106-0031 東京都港区西麻布3-24-20 TEL03-5410-0242 FAX03-5410-1822 